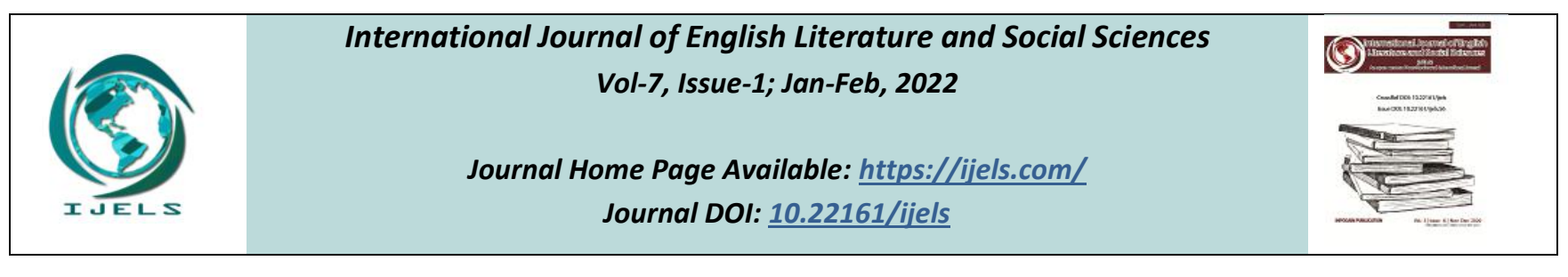

Peer-Reviewed Journal

\title{
Madness and Corruption in Shakespeare: Hamlet and Macbeth
}

\author{
Anusha Sanyal
}

M.A Student, Lady Brabourne College. Kolkata, India

Received: 11 Dec 2021; Received in revised form: 22 Jan 2022; Accepted: 30 Jan 2022; Available online: 07 Feb 2022

C2022 The Author(s). Published by Infogain Publication. This is an open access article under the CC BY license

(https://creativecommons.org/licenses/by/4.0/).

\begin{abstract}
Corrupting Influence of Power in Shakespeare's Plays". Lord Acton splendidly maintained that "power tends to corrupt. And absolute power corrupts completely." Shakespeare's plays qualify as such a lot of ingenious investigations into the implications of possessing power. The dramatic portrayal of madness will usually be a cathartic expertise for audiences. By looking at actors perform mentally disturbed characters, audiences ar freed momentarily to observe their own stresses, fears, pressures and pent-up needs showing emotion lived out of body through a example of life on the stage
\end{abstract}

Keywords-Shakespeare, Corruption, mental illness.

\section{INTRODUCTION}

As the medieval age gave thanks to the Renaissance, the thought persisted that order depends on a close gradable society with a legitimate leader at the highest, typically even ordained by God. Also, the sturdy humanistic plan persisted that the role of a ruler was to create the welfare of the state and its voters his priority. To subvert that and create his own self-interest his main priority is to corrupt that ideal. Corruption seems in several forms in Shakespeare. At its most evident level, corruption is joined to power and that we see innumerable samples of corruption within the most powerful characters in the plays. Shakespeare's depiction attribute through all his plays reveals the corruption that infects groups of people. Shakespeare usually explores the ways that within which kings and alternative powerful figures abuse their position, yet because the ways that within which formidable men plot to achieve power, typically the throne, by illegitimate means.

Before we plunge into the fascinating depictions of various psychiatrical sicknesses at intervals his characters, allow us to have a glance at the standing of psychological state in sixteenth century England and also the theories that prevailed in Elizabethan England relating to psychological state. There will be little doubt that poet was fascinated by psychiatrical sickness. Funnily enough, his writings not solely contain characters plagued with mental disorders however additionally depict a information of physical sickness and sickness the accuracy of that doesn't fail to impress upon his readers.

\section{CORRUPTION IN KING}

In the play 'Macbeth' by Shakespeare, the theme of corruption is clearly angry throughout the course of the play. It's introduced by the utilization of the supernatural and through the theme of ambition and may be a integral to our understanding of the plot. By Macbeth's murder of Duncan, the order of the universe was corrupted. We all know this as a result of as presently because the murder passed, there have been abnormal climate, that consisted of thunder and lightning, on the witches' entrance, and storms on the night Macbeth performed regicide and killed King Duncan. Another issue of Shakespeare's play, Macbeth, that shows the theme of corruption is Macbeth plotting to kill his succor, Banquo. Macbeth's power and ambition to become king ends up in worry, doubt and lack of trust between Banquo and himself that ends up in the isolation of Macbeth from god, his friends and his society. Lastly, Shakespeare gains the audience's understanding of the theme of corruption through Macbeth's side comments, relationships with alternative characters within the play, his sheer 
aspiration to fulfill his goals and his loyal frame of mind. The theme of corruption is introduced to us by the utilization of supernatural wherever the witches tell him a prophecy, by that he follows from then on, and is set to hold out no matter what he should to create for this prophecy to become a reality.

\subsection{Madness in king}

A Guilty Conscience: However guilt drives the powerful to mental illness. Guilt is the reason for the destruction of many, significantly in Shakespeare's Tragedy of Macbeth. As Macbeth and Lady Macbeth still murder for the sake of power, they start opposite journeys, however their guilt ultimately drives them each to madness. Macbeth goes from being driven mad with guilt, to his instability inflicting him to murder recklessly. Additionally, madness is additionally connected to Macbeth's ambition. He's therefore involved with preventing the prophecy concerning Banquo's sons from coming back true, that he has Banquo dead and later sees his ghost. Banquo's ghost is, therefore, a comprehensible illustration of his ambition still as his guilt. Because the story of Macbeth progresses, the most character, Macbeth's, sanity spirals to the purpose of madness. Theoretical man of science Albert Einstein outlined madness as "doing constant issue over and another time and expecting completely different results." This definition absolutely explains how Macbeth became insane. This can be seen throughout the story, Macbeth goes on to kill anyone he believes is aware of him murdering King Duncan. In Act III scene ii, king says "We have scotch'd the snake, not kill'd it. She'll shut and be herself, while our poor malice remains in peril of her former tooth" (III.ii.15- 17). Macbeth believes that if he finishes off the "snake," then he is going to be safe. This doesn't work; for not solely will the "snake" not die, its final kind grows larger and deadlier. The war in Act V is that the final variety of the snake. Also, the "snake" may be a relevancy to the snake with Adam and Eve. Macbeth believes that he is going to be fighting off evil with a lot of evil. This can be a manner by which William Shakespeare makes connections to reality. Lady Macbeth is additionally another major character that's overcome by madness. Her threshold to madness starts in Act I scene v, wherever she provides a monologue concerning however she desires spirits to "unsex me here / . . / . . Come to my woman's breasts, / And take my milk for gall," " (I.v.42-44) Seeing however madness earlier was outlined as some possessed by a wicked power, Lady Macbeth would beyond any doubt be classified as "mad". The spirits she talks to the current scene refers to a demon of some kinds. Through this scene, the reader discovers that not solely will Lady Macbeth become possessed by a "demon," she craves it.

\subsection{Corruption in Hamlet}

"Upon my secure hour thy uncle scarf

With juice of cursed hebona during a ampule,

And within the porches of my ears did pour

The leprous distilment"

The first and central Incidence of corruption in Hamlet is that the murder of King Hamlet by Claudius and his resulting usurpation of the Danish. He conjointly marries Gertrude, King Hamlet's former wife. From Associate in Nursing Elizabethan perspective, such a wedding are thought of as controversial and unlawful carnal. "She married - O worst speed! To post with such manual dexterity to incestuous sheets! It's not, nor it cannot come back to sensible." (1.2.156.158). King Hamlet's assassination takes place before the play's narrative begins. We tend to adapt, concerning it by King Hamlet's ghost: "The serpent that did sting thy father's life currently wears his crown" (1.5.39-40). This "primal eldest curse," a brother's murder, is the crux of the play, the crucial event that triggers all the corruption and intrigue. As Hamlet puts it: "Ay, sir, to be honest as this world goes is to be one man picked out of 10 thousand." (2.2.178-79). His obsession with corruption imbues his senses for many elements of the play. Shakespeare's depiction of attribute through all his plays reveals the corruption that infects personalities. Corruption seems in several forms in William Shakespeare. At its most blatant level, corruption is connected to power and that we see innumerable samples of corruption within the most powerful characters within the plays. William Shakespeare usually explores the ways that during which kings and alternative powerful figures abuse their position, still because the ways that during which formidable men plot to realize power, sometimes the throne, by illegitimate means.

\subsection{Madness in Hamlet}

Throughout the play, Hamlet displays several characteristics indicative of madness. At the start of the play, Hamlet is visited by the ghost of his father. Seeing a ghost may indicate that he's already mad. His father's ghost tells him that he was murdered by Claudius, that drives Hamlet to require to hunt revenge. This causes him to show erratic behavior, indicating that he has become mad together with his need to avenge his father's death. He additionally becomes quite melancholic over the death and murder of his father and begins to question life, as a result. Whereas Hamlet feels the necessity to penalise his father's death, he additionally worries that the ghost may very well "be a devil who can betray his soul," instead of the particular ghost of his father (Frye, 12). This makes Hamlet confused on what he ought to truly waste response to seeing the ghost and drives him additional into madness. Another character which will be construed as mad in 'Hamlet' is Ophelia. 
Ophelia is represented as a weak character who is unable to suppose clearly for herself or to own any sense of individuality. Early within the play Ophelia says to her father, Polonius, "I don't grasp, my lord, what I ought to think" (Shakespeare). This means that she is simply too weak-willed to own AN identity of her own, that may indicate some kind of psychopathy or "madness." Her father's identity is her identity and this loss of identity propelled her additional into madness.

\section{CONCLUSION}

Madness is one in all the most themes of 'Hamlet'. Hamlet and Ophelia each show symptoms of madness, however every become mad for various reasons. Hamlet's madness is burning by his father's death and his need to hunt revenge on the person who killed him. Ophelia's madness stems from her lack of identity and her feelings of helplessness relating to her own life. Whereas the death of Hamlet's father created him angry enough to require revenge, Ophelia internalized the death of her father as a loss of private identity. Whereas these deaths each sparked madness in these characters, they every prohibited their madness in numerous ways that. This is often additional urged by the good decline and destruction that Lady Macbeth and Macbeth face at the beginning of the play despite their sturdy and dominant portrayal at the start of the play. This decline and destruction is primarily aroused by the madness that took over their status, that is represented once each of them to own sleepless nights and frightful hallucinations. Thus, madness during this context is importance as a medium to convey to readers the ethical lesson that's embedded within the play. Overall, madness plays an important role within the play 'Macbeth', written by the bard who strategically connected the thought of madness to two important characters Macbeth and Lady Macbeth. The theme of madness helped to make known to readers the event of each the characters through presenting the characters with conflicts among themselves.

\section{REFERENCES}

[1] Melancholy, Hysteria and Madness in Shakespeare's Tragedies Hamlet, Macbeth and King Lear through the Psychoanalytical Prism of Julia kristeva

[2] The madness of Hamlet and King Lear: When psychiatrists used Shakespeare to argue legal definitions of insanity in the courtroom - Shakespeare and Beyond

[3] Shakespeare, Madness and Threatened Identities- Brook Johnson

[4] The Power Of Madness In Shakespeare's Macbeth And Madness

[5] Corruption and Theories of Kingship in Macbeth- Michelle A. Labbe
[6] Shakespeare: Hamlet - Corruption is an incurable diseaseLSJ

[7] The Madness of Hamlet and Ophelia: Mental Illness in Shakespeare- Jennifer Wilber

[8] MADNESS IN LITERATURE: SHAKESPEARE AND MENTAL ILLNESS - Fatima Altaf 